\title{
CORRESPONDENCE
}

\section{ASCORBIC ACID IN THE TREATMENT OF CORNEAL LESIONS}

To the Editors of THE BRITISH JOURNAL OF OPHTHALMOLOGY.

DEAR SIRS-In the communication from us on the treatment of corneal lesions with ascorbic acid published in the June issue of the Journal we stated that the injections used were "Roche" concentrated vitamin " $\mathrm{C}$ " ampoules. Through an unfortunate oversight we omitted to say that in a number of cases, "Celin Forte" prepared by the Glaxo Laboratories, Ltd., was employed. With neither product was there any reaction, local or general, and the results obtained were strictly comparable.

We shall be glad if you will permit us to repair this omission.

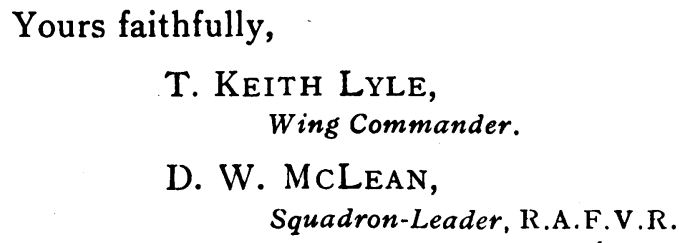
Squadron-Leader, R.A.F.V.R.

August 8, 1941.

\section{HYPEREMESIS GRAVIDARUM}

To the Editors of THE BRitish Journal of Ophthalmology.

DEAR SIRS, - I have read with much interest the paper of $\mathrm{Mr}$. George Black in the September number of the Journal, since it throws further light on the subject of my own paper referred to in your Annotation in the same number.

As Mr. Black states, Campbell and Biggart have shown that Wernicke's syndrome may have many different antecedents, such as chronic alcoholic poisoning, gaștric carcinoma, hyperemesis gravidarum, pernicious anaemia, chronic gastritis and others. Investigators have not yet discovered the etiological factor common to all these ; but a consideration of the cases of hyperemesis gravidarum suggests that in this condition some form of pregnancy toxaemia causes the persistent vomiting, with loss or destruction of the available vitamin $\mathrm{B}_{1}$, leading in turn to the characteristic polyneuritis, retrobulbar optic neuritis and cerebral and ocular haemorrhage. A somewhat 